(C) 2019 International Journal of Nursing and Health Services

This is an Open Access article distributed under the terms of the Creative Commons Attribution 4.0 International License.

ORIGINAL ARTICLES

\title{
FACTORS ASSOCIATED WITH CARING AMONG ELDERLY WITH END OF LIFE
}

\author{
Eva Riantika Ratna Palupi ${ }^{*}$, Ah. Yusuf ${ }^{2}$ \\ 1. Faculty of Nursing Universitas Airlangga, Surabaya \\ 2. Faculty of Nursing Universitas Airlangga, Surabaya \\ * Correspondence: eva.riantika.ratna-2017@fkp.unair.ac.id
}

\begin{abstract}
The elderly potentially getting the multimorbid disease and chronic disease. Chronic disease through the elderly needs an end of life care. The purpose of this study was to found the factors related to the perceptions of end of life care using health belief models. Design of this study was the explanatory survey with a crosssectional approach. The samples were 118 elderlies in Puskesmas Jatikalen area, Nganjuk Regency. Independent variables were demography (age and gender), sociopsychological (social class), structural (knowledge), perceived susceptibility, perceived seriousness, perceived benefits, and perceived barriers. The dependent variable was the end of life care. Data were collected by interview using a questionnaire. Data were analyzed using chi-square. Factors related to end of life care in the elderly were age ( $p$-value $=0.049$ ), gender ( $p$-value $=0.001$ ), social class ( $p$-value $=0.002)$, knowledge ( $p$-value $=0.0048)$, perceived susceptibility $(\mathrm{p}$-value $=0.039)$, perceived seriousness $(\mathrm{p}$-value $=0.025)$, perceived benefits $(\mathrm{p}$-value $=$ 0.000 ), and perceived barriers ( $p$-value $=0.000$ ). The factors related to the end of life care are age, gender, social class, knowledge, perceived susceptibility, perceived seriousness, perceived benefits, and perceived barriers. This study was recommended to apply to the elderly with chronic illness, especially at the community.
\end{abstract}

Keywords: end of life care, elderly, health belief model

International Journal of Nursing and Health Services (IJNHS), September 2019, Volume 2, Issue 3; Page 142-149

Received: 27 June 2019; Revised: 19 July 2019; Accepted: 23 July 2019

DOI: http//doi.org/10.35654/ijnhs.v2i3.158

\section{Introduction}

Epidemiology shifts to the old age with multimorbid diseases and chronic diseases (1). Chronic disease affects the elderly to get the end of life care (2). Chronic diseases generally attack the elderly. Intensive care is not only useful in extending their life expectancy. They are much more likely to die slowly and proceed with joint death than having to spend the rest with a disease that must be treated in the hospital (3). The family in providing end of life care for the elderly does not have a standard that must be done yet so that it is found that the elderly are treated by the family in a situation that is not as expected (4). 
The number of elderly in the world reached 901 million in 2015, equivalent to $(12.3 \%)$ of the entire world population. Asia has 508 million elderlies, which shows that the number of older adults in Asia constitutes half (50\%) of the number of older adults worldwide (5). Indonesia is an Asian state with a total of 20.24 million elderlies, equivalent to $8.03 \%$ of the total population of Indonesia (6). The number of Indonesian elderly has not been balanced with good health. Elderly morbidity rates in Indonesia were calculated with a percentage of $25.05 \%$, meaning that out of every 100 elderlies, 25 elderlies were sick (7). The morbidity rate of the elderly is because of chronic disease in the highest order, such as hypertension, arthritis, stroke, COPD, DM, cancer, coronary heart disease, kidney stones, heart failure, and kidney failure (8).

Studies that discuss the end of life care in the elderly have been widely carried out. Cultural, belief, educational, socio-economic differences, family roles greatly influence the end of life care of the elderly. The background results are different from the effects of landscape research, which are intended not to live longer with medical devices, and life care decision-makers are accepted by other people or families (9).

The theory underlying this research is the Health Belief Model. The central concept of the Health Belief Model is a theory used to evaluate and explain individual differences in preventive health behavior. The central idea of HBM theory is that healthy behavior is determined by personal beliefs or perceptions of the disease and the means available to avoid infection (10).

\section{Objectives}

The study aimed to analyze the factors associated with caring among elderly with the end of life

\section{Methods}

3.1 Research design

The design used in this study was an explanatory survey, which is a way to explore new things and explain causal relationships of independent variables and dependent variables (11). The approach used in this study was cross-sectional, that emphasizes the time of observation or data collection at once at a time (12).

3.2 Setting, samples, sampling technique

The research was conducted in Puskesmas Jatikalen area, Nganjuk Regency. The samples were selected using purposive sampling technique approximately 118 elderlies with chronic illnesses.

3.3 Instruments

The instruments used in this research were adopted and modified questionnaire of Health Belief Model (HBM) questionnaire by Kristen M. Frankenfield (2009).

3.4 Ethical consideration

The research maintains ethical ethics by paying attention to the three main principles of research ethics: benefit, respect for human rights (respect human dignity), and justice (right to judge) (13). Therefore, data retrieval is preceded by obtaining approval from the respondents who being researched and as the subject of the study while emphasizing ethical issues which include: the right to guarantee (right to full disclosure), informed consent sheet, approval form (without a name), and confidentiality. This study has been declared following the ethical decision 
letter of the Health Research Ethics Commission of the Faculty of Nursing, Airlangga University Number 1341-KEPK.

\subsection{Data analysis}

The data was analyzed by chi-square to answer the correlation between each variables using Statistical Package for the Social Sciences (SPSS).

\section{Results}

This following table explained the results of the research:

Table 1. Frequencies and Percentages of Ages towards End of Life Care

\begin{tabular}{lccccccc}
\hline \multirow{2}{*}{ Age } & \multicolumn{6}{c}{ End of Life Care } & \multirow{2}{*}{$p$} \\
\cline { 2 - 7 } & \multicolumn{2}{c}{ No } & \multicolumn{2}{c}{ Yes } & \multicolumn{2}{c}{ Total } & \\
\cline { 2 - 7 } & $\mathrm{N}$ & $\%$ & $\mathrm{~N}$ & $\%$ & $\mathrm{~N}$ & $\%$ & \\
\hline Early elderly & 43 & $37 \%$ & 5 & $4 \%$ & 99 & $84 \%$ & \\
\hline Elderly & 10 & $8 \%$ & 56 & $47 \%$ & 15 & $13 \%$ & 0.049 \\
\hline Old elderly & 3 & $2 \%$ & 1 & $2 \%$ & 4 & $3 \%$ \\
\hline Total & 56 & $47 \%$ & 62 & $53 \%$ & 118 & $100 \%$ & \\
\hline
\end{tabular}

The results showed that 62 elderlies (53\%) got the end of life care, and most of them were elderly / 70-75 year old (47\%). The relation between age and end of life care were significant with p-value 0.049 .

Table 2. Frequencies and Percentages of Gender towards End of Life Care

\begin{tabular}{lccccccc}
\hline \multirow{2}{*}{ Gender } & \multicolumn{6}{c}{ End of Life Care } & \multirow{2}{*}{$p$} \\
\cline { 2 - 7 } & \multicolumn{2}{c}{ No } & \multicolumn{2}{c}{ Yes } & \multicolumn{2}{c}{ Total } & \\
\cline { 2 - 7 } & $\mathrm{N}$ & $\%$ & $\mathrm{~N}$ & $\%$ & $\mathrm{~N}$ & $\%$ & \\
\hline Man & 25 & $21 \%$ & 11 & $9 \%$ & 36 & $31 \%$ & \multirow{2}{*}{0.001} \\
\hline Woman & 31 & $26 \%$ & 51 & $44 \%$ & 82 & $69 \%$ \\
\hline Total & 56 & $47 \%$ & 62 & $53 \%$ & 118 & $100 \%$ & \\
\hline
\end{tabular}

The results showed that 62 elderlies (53\%) got the end of life care, and most of them were women $(44 \%)$. The relation between gender and end of life care were significant with p-value 0.001 . 
Table 3. Frequencies and Percentages of Social Class towards End of Life Care

\begin{tabular}{lccccccc}
\hline \multirow{3}{*}{ Social Class } & \multicolumn{6}{c}{ End of Life Care } & \multirow{2}{*}{$p$} \\
\cline { 2 - 7 } & \multicolumn{3}{c}{ No } & \multicolumn{2}{c}{ Yes } & \\
\cline { 2 - 7 } & $\mathrm{N}$ & $\%$ & $\mathrm{~N}$ & $\%$ & $\mathrm{~N}$ & $\%$ \\
\cline { 2 - 7 } Low Social Class & 35 & $29 \%$ & 21 & $18 \%$ & 56 & $47 \%$ & \\
\hline High Social Class & 21 & $18 \%$ & 41 & $35 \%$ & 62 & $53 \%$ & \\
\hline Total & 56 & $47 \%$ & 62 & $53 \%$ & 118 & $100 \%$ & \\
\hline
\end{tabular}

The results showed that 62 elderlies (53\%) got the end of life care, and most of them were high social class (35\%). The relation between social class and end of life care were significant with p-value 0.002 .

Table 4. Frequencies and Percentages of Knowledge towards the End of Life Care

\begin{tabular}{|c|c|c|c|c|c|c|c|}
\hline \multirow{3}{*}{ Knowledge } & \multicolumn{6}{|c|}{ End of Life Care } & \multirow[t]{3}{*}{$p$} \\
\hline & \multicolumn{2}{|c|}{ No } & \multicolumn{2}{|c|}{ Yes } & \multicolumn{2}{|c|}{ Total } & \\
\hline & $\mathrm{N}$ & $\%$ & $\mathrm{~N}$ & $\%$ & $\mathrm{~N}$ & $\%$ & \\
\hline Enough & 33 & $28 \%$ & 26 & $22 \%$ & 59 & $50 \%$ & \\
\hline Good & 23 & $19 \%$ & 36 & $31 \%$ & 59 & $50 \%$ & 0.048 \\
\hline Total & 56 & $47 \%$ & 62 & $53 \%$ & 118 & $100 \%$ & \\
\hline
\end{tabular}

The results showed that 62 elderlies (53\%) got the end of life care, and most of them had good knowledge about end of life care (31\%). The relation between philosophy and end of life care were significant with p-value 0.048 .

Table 5. Frequencies and Percentages of Perceived Susceptibility towards End of Life Care

\begin{tabular}{|c|c|c|c|c|c|c|c|}
\hline \multirow{3}{*}{$\begin{array}{c}\text { Perceived } \\
\text { Susceptibility }\end{array}$} & \multicolumn{6}{|c|}{ End of Life Care } & \multirow[t]{3}{*}{$p$} \\
\hline & \multicolumn{2}{|c|}{ No } & \multicolumn{2}{|c|}{ Yes } & \multicolumn{2}{|c|}{ Total } & \\
\hline & $\mathrm{N}$ & $\%$ & $\mathrm{~N}$ & $\%$ & $\mathrm{~N}$ & $\%$ & \\
\hline Positive & 29 & $24 \%$ & 43 & $36 \%$ & 72 & $61 \%$ & \\
\hline Negative & 27 & $23 \%$ & 19 & $17 \%$ & 46 & $39 \%$ & 0.039 \\
\hline Total & 56 & $47 \%$ & 62 & $53 \%$ & 118 & $100 \%$ & \\
\hline
\end{tabular}

The results showed that 62 elderlies (53\%) got the end of life care, and most of them had positively perceived susceptibility about chronic ill (36\%). The relation between perceived vulnerability and end of life care were significant with p-value 0.039 . 
Table 6. Frequencies and Percentages of Perceived Seriousness towards End of Life Care

\begin{tabular}{|c|c|c|c|c|c|c|c|}
\hline \multirow{3}{*}{ Perceived Seriousness } & \multicolumn{6}{|c|}{ End of Life Care } & \multirow[t]{3}{*}{$p$} \\
\hline & \multicolumn{2}{|c|}{ No } & \multicolumn{2}{|c|}{ Yes } & \multicolumn{2}{|c|}{ Total } & \\
\hline & $\mathrm{N}$ & $\%$ & $\mathrm{~N}$ & $\%$ & $\mathrm{~N}$ & $\%$ & \\
\hline Positive & 30 & $25 \%$ & 45 & $38 \%$ & 75 & $64 \%$ & \multirow{3}{*}{0.025} \\
\hline Negative & 26 & $22 \%$ & 17 & $15 \%$ & 43 & $36 \%$ & \\
\hline Total & 56 & $47 \%$ & 62 & $53 \%$ & 118 & $100 \%$ & \\
\hline
\end{tabular}

The results showed that 62 elderlies (53\%) got the end of life care, and most of them had positively perceived seriousness about chronic ill (38\%). The relation between perceived severity and end of life care were significant with p-value 0.025 .

Table 7. Frequencies and Percentages of Perceived Benefits towards End of Life Care

\begin{tabular}{lccccccc}
\hline \multirow{2}{*}{ Perceived Benefits } & \multicolumn{6}{c}{ End of Life Care } & \multirow{2}{*}{$p$} \\
\cline { 2 - 7 } & \multicolumn{3}{c}{ No } & \multicolumn{3}{c}{ Yes } & \multicolumn{2}{c}{ Total } & \\
\cline { 2 - 7 } & $\mathrm{N}$ & $\%$ & $\mathrm{~N}$ & $\%$ & $\mathrm{~N}$ & $\%$ & \\
\hline Positive & 18 & $15 \%$ & 48 & $41 \%$ & 66 & $56 \%$ & \multirow{2}{*}{0.000} \\
\hline Negative & 38 & $32 \%$ & 14 & $12 \%$ & 52 & $44 \%$ & \\
\hline Total & 56 & $47 \%$ & 62 & $53 \%$ & 118 & $100 \%$ & \\
\hline
\end{tabular}

The results showed that 62 elderlies (53\%) got the end of life care, and most of them had positive perceived benefits about the end of life care $(41 \%)$. The relation between perceived benefits and end of life care were significant with p-value 0.000 .

Table 8. Frequencies and Percentages of Perceived Barriers towards End of Life Care

\begin{tabular}{lccccccc}
\hline \multirow{2}{*}{ Perceived Benefits } & \multicolumn{6}{c}{ End of Life Care } & \multirow{2}{*}{$p$} \\
\cline { 2 - 7 } & \multicolumn{3}{c}{ No } & \multicolumn{3}{c}{ Yes } & \multicolumn{2}{c}{ Total } & \\
\cline { 2 - 7 } & $\mathrm{N}$ & $\%$ & $\mathrm{~N}$ & $\%$ & $\mathrm{~N}$ & $\%$ & \\
\hline Positive & 34 & $29 \%$ & 55 & $46 \%$ & 89 & $75 \%$ & \multirow{2}{*}{0.000} \\
\hline Negative & 22 & $18 \%$ & 7 & $7 \%$ & 29 & $25 \%$ \\
\hline Total & 56 & $47 \%$ & 62 & $53 \%$ & 118 & $100 \%$ & \\
\hline
\end{tabular}

The results showed that 62 elderlies (53\%) got the end of life care, and most of them had positively perceived barriers about the end of life care (46\%). The relation between perceived obstacles and end of life care were significant with p-value 0.000 .

\section{Discussion}

The results showed that demographic factors (age and sex) had a significant relationship with the end of life care. This study supported that age and sex influence the perception of threats to a disease that is believed to influence the likelihood of 
taking preventive health action (10). Demographic factors in this study showed that the age of the elderly between 70-75-year-old was more enjoyable to do the end of life care during their chronic illness. This term is in line with the research, where the end of life care is mostly carried out at the age of the elderly (average age 78 years) (2). Another study also mentions in conducting end of life care in line with age at an average age of 70 (14).

Gender has a significant relationship on end of life care, in this study is female. The results of this study were supported by previous research that end of life care was influenced by sex factors (most women), high dependence, severe cognitive damage, elderly living with their families, and primary diseases such as cancer followed by dementia (2). The other research in line with the results of this study reinforces the finding that the age and sex factors of the old influence the elderly in making decisions for end of life care (15).

The second factor is sociopsychologist consisting of social class. These findings indicate that a right level of social quality, where the elderly have savings / insurance or well finance families of the elderly, increasingly make the perception of the positive elderly to carry out the end of life care. This is in line with previous research that several factors hinder the conduct of end of life care, one of which is finance. Lack of funding makes the elderly not to impose the end of life care on their family due to their illness (3). The other hand, in lousy finance, the majority of the respondents stated that they were better treated at home than in the hospital (15). The last is a structural factor consisting of knowledge of the elderly. Good understanding of the elderly affects the perception of the elderly towards chronic illness. This variable is in line with the HBM factor theory that sociodemography, especially education and knowledge, is believed to have an indirect effect on behavior by influencing the perceptions (10). The results of this study about the opinions of the elderly found that the elderly had a positive attitude. Elderly have a positive susceptibility. Elderly feel as a group vulnerable to chronic diseases. In this study, the elderly found it easy to complain of pain, felt at risk of getting a more severe illness, felt anxious, and thought that it could be worse tomorrow. This research is in line with previous studies of anxiety about the end of life, accompanied by chronic diseases to multiple trauma. They think that everything will go as it should but remain open to the end of life nursing planning. Although not formally planned (16).

The other perception of the elderly has an understanding of real seriousness. Elderly feel that they suffer from a chronic illness that is a severe disease. Elderly states that chronic diseases that are being experienced make them afraid, not even hope to recover and long will end. In this study, it was found that the elderly were fearful of their illness, felt anxious to pound when the disease recurred, even had time to think that the condition suffered would last long, and there was no hope of recovery. This incident is supported by previous research that the severity or seriousness of a disease affects decision making in the elderly on the problem of life-threatening complex care (17).

The third perception is a positive, perceived benefit. Elderly feels that end-oflife care is something useful. When the elderly get final attention, the elderly feel quieter, feel better in living life, and are excited/optimistic about living longer. Previous research supports that end of life care is used both at home and in health

International Journal of Nursing and Health Services (IJNHS), Volume 2, Issue 3, September 2019147 
services so that the elderly feel peaceful at the end of their lives (18). The fourth perception is positively perceived barriers. This study found no obstacles that were thought by the elderly. Elderly do not agree if chronic diseases have no hope for recovery, even though sometimes they are bored following the end of life care. Access to end of life care can also be reached. This is supported by previous research that determining the end of life care has barriers, including not feeling sick, being too young, and not understanding the proper care (14). The result of positive perceptions of the elderly on perceived susceptibility, seriousness, benefits, and barriers causes the elderly to carry out the end of life care. This is in line with HBM theory that positive perceptions of the elderly are used in encouraging someone to accept healthy behavior (19). The positive perceived susceptibility, seriousness, benefits, and barriers to the elderly are exactly influencing at the end of life care; thus, the elderly will get the peaceful end of life. This statement in line that the end of life care can make the quiet end of life (20)

The other hands in this research, the variable end of life care in this study showed that the family treated the majority. Most of elderly preferred to get the end of life care at home. This research in line with the previous study that nearly $60 \%$ of respondents said they were better treated at home than in hospitals if they had an incurable disease (15). The other study showed that the elderly were preferred receiving an end of life care at home (nursing care at home) in the last month of their life (2).

\section{Conclusion}

The factors related to the perceptions of end of life care are age, gender, social class, and knowledge. The most significant factor related to end of life care were gender. Most women will do the end of life care in the condition with chronic illness.

\section{Strength and Limitation}

The advantage of this study can explain the background factor that influences the elderly to do the end of life care, including age, gender, social class, knowledge, perceived susceptibility, perceived seriousness, perceived benefits, and perceived barriers. Thus a nurse can make a point of view to assess the elderlies needs about the end of life care correctly based on those factors. This study has a limitation that doesn't investigate the correlation between other elements in the Health Belief Model thoroughly, such as cues to the action of the elderly. The other of the limitation, including family and health practitioner background in influencing end of life care to the elderly.

\section{References}

1. Novellas JA, Espaulella J, Rexach L, Fontecha B, Inzitari M, Blay C, et al. Frailty, severity, progression, and shared decision-making: A pragmatic Framework Life, for the challenge of clinical complexity at the end of life. Eur Geriatr Med. 2015;6:189-94.

2. Nakanishi M, Niimura J, Nishida A. Factors associated with end-of-life by home-visit nursing-care providers in Japan. 2016;

3. Periyakoli VS, Neri E, Kraemer H. Patient-Reported Barriers to High-Quality, End-of-Life Care: A Multiethnic, Multilingual, Mixed-Methods Study 1,2 1. 2015;18(X). 
4. Yuhono P. Gambaran peran keluarga dalam merawat lansia dengan ketergantungan di desa pabelan. 2017;

5. BPS. Statistik Penduduk Usia Lanjut 2017. Jakarta; 2017.

6. BPS. Statistik Penduduk Lansia 2014. 2014.

7. KemenkesRI. Gambaran Kesehatan Lanjut Usia di Indonesia. Jakarta; 2013.

8. Kementerian Kesehatan RI. Undang-undang Republik Indonesia Nomor 38 Tahun 2014 tentang KeperawatanKementerian Kesehatan RI. (2014). Undang-undang Republik Indonesia Nomor 38 Tahun 2014 tentang Keperawatan, Kemenkes RI. Retrieved from https://www.kemenkopmk.go.id/sites/default/file. 2014; Kemenkes, RI.

9. Ho S, Sanders GF. Preferences on End-Of-Life Decisions Among Older Chinese in Macau. 2015;

10. Alligood MR. Nursing Theorists and Their Work. USA: Elsevier Mosby; 2014.

11. Sugiyono. Metode Penelitian Kuantitatif, Kualitatif, dan R\&D. Bandung: Alfabeta; 2015.

12. Notoatmodjo S. Metodologi Penelitian Kesehatan. Jakarta: Rineka Cipta; 2012.

13. Nursalam. Metodologi Penelitian Ilmu Keperawatan. Jakarta: Salemba Medika; 2015.

14. Boucher NA. and Fate : Dominican and Puerto Rican Elders' Perspectives on End-of-Life Decisions. 2017;

15. Ohr S, Officer ML, Service MH, Jeong S, Saul P. No Title. 2016;

16. Dennis MK, Washington KT. "Just Let Me Go ": End-of-Life Planning Among Ojibwe Elders. 2016;00(00):1-8.

17. Espaulella J, Rexach L, Fontecha B, Inzitari M, Blay C. ScienceDirect Frailty, severity, progression, and shared decision-making: A pragmatic framework for the challenge of clinical complexity at the end of life. 2015;6:189-94.

18. Zuckerman RB, Stearns SC, Sheingold SH. Hospice Use, Hospitalization, and Medicare Spending at the End of Life. 2015;00(00):1-12.

19. Rosenstok I. Historical Origin of the Health Belief Model. In 1974. p. 328-35.

20. Ruland CM, Moore SM. Theory Construction Based on Standards of Care : A Proposed Theory of the Peaceful End of Life. 1998;(August). 